\title{
Comparison of Shock Wave Parameters of in Situ ESWL \& ESWL After Push Back for Upper Ureteric Calculi
}

\author{
Sakhawat Mahmud Khan ${ }^{1 *}$ \\ Shahin Akhter ${ }^{2}$ \\ S A M Golam Kibria ${ }^{3}$ \\ Isteaq Ahmed Shamim ${ }^{4}$ \\ Shireen Akhter Khanam ${ }^{4}$ \\ ${ }^{1}$ Department of Urology \\ Chittagong Medical College \\ Chittagong, Bangladesh. \\ ${ }^{2}$ Department of Physiology \\ Chittagong Medical College \\ Chittagong, Bangladesh. \\ ${ }^{3}$ Department of Urology \\ Bangabandhu Sheikh Mujib Medical University \\ Dhaka, Bangladesh. \\ ${ }^{4}$ Depatment of Obstetrics \& Gynaecology \\ Chittagong General Hospital \\ Chittagong, Bangladesh.
}

*Correspondence to:

\section{Dr. Sakhawat Mahmud Khan}

Assistant Professor

Department of Urology

Chittagong Medical College

Chittagong, Bangladesh.

Mobile : +88 01814902579

Email: k.sakhawat@ymail.com

\begin{abstract}
Background: To compare the shock wave parameters of in situ ESWL \& ESWL after push back for upper ureteric calculi. Methods: This hospital based prospective study was carried out in the Department of Urology, Bangabandhu Sheikh Mujib Medical University (BSMMU) Dhaka from January 2006 to December 2006. For this study, 90 patients were selected according to the selection criteria. They were divided into two groups. Group 1 included 50 patients treated by in situ ESWL and group 2 included 40 patients treated by push back and ESWL. For statistical analysis, student's t- test \& chi-square test were performed. Results: In group 1 and in group 2 patients mean age were $34.86 \pm 11.74$ years and $35.12 \pm 12.48$ years respectively. In group 1: Over all clearance of calculi was $92.86 \%$ in $1 \mathrm{~cm}$ stones and $86.36 \%$ in $1 \mathrm{~cm}$ stones $(\mathrm{p}>0.05$ ). In group 2: Total clearance was $100 \%$ in stones $<1 \mathrm{~cm}$ size and $88 \%$ in $1 \mathrm{~cm}$ size stones ( $>0.05$ ). Although clearance rate was higher in push back group it was not statistically significant (92.5\% Vs.90\%) (p>0.05). Number of ESWL session in case of $<1 \mathrm{~cm}$ size stone were 1.54 in group 1 and 1.46 in group 2. In case of $1 \mathrm{~cm}$ size stone, it was 1.77 in group $1,1.48$ in group 2 ( $>0.05$ ). Considering the requirement of shock wave number, less shock wave were required in group $2(1757.50 \pm 255.09)$ than group $1(1994 \pm 449.22)(\mathrm{p}<0.01)$. Mean energy needed in group I was $5.07 \pm 0.81$ and in group 2 it was $4.63 \pm 0.48$ $(\mathrm{p}<0.01)$. Conclusion: Although more ESWL sessions were required in group 1 than group 2, it was not statistically significant. But mean shock wave number and energy were higher in group 1 than group 2 which was statistically significant.
\end{abstract}

Key words: Upper ureteric calculi; In situ ESWL; ESWL after push back; Shock wave session and shock wave energy.

\section{INTRODUCTION}

Urolithiasis is the common disease of the urinary tract ${ }^{1}$. Exact data about its prevalence is not known in Bangladesh but it is quite common as seen in out patient department. It is more common in northern part of the country. Male suffer more than female $(\mathrm{M}: \mathrm{F}-3: 1)^{2}$. Complications like pyonephrosis, septicaemia, pyelonephritis, hydronephrosis, renal failure and even death occur due to untreated stone disease. So treatment of stone disease is necessary to avoid complications. There are different modalities of treatment options for urolithiasis like Extracorporeal Shock Wave Lithotripsy (ESWL) Percutaneous Nephrolithotomy (PCNL) Ureterorenoscopy (URS) and laparoscopic removal. But one option can supplement the other for total stone clearance ${ }^{3}$. ESWL has revolutionized the treatment of urinary calculi with the concept to disintegrate stones discovered in 1950 in Russia. The first clinical application with successful fragmentation of renal calculi was in 1980. Since then, there are several modifications of the models of the instruments and are still continuing ${ }^{4}$. 
In Bangladesh Siemens lithostar plus lithotriptor was introduced for the first time in 1993 in BSMMU, Dhaka ${ }^{5}$. Because of extensive research and technological developments ESWL machines are becoming safe, more effective and less costly with every generation of new machine. High patient compliance and safety has made ESWL, the primary method of modality of management of stone disease. Since the introduction of ESWL for the treatment of renal stones, indications of the procedure have rapidly extended to the treatment of ureteral calculi ${ }^{6}$. As a guideline, owing to its greater efficacy and lower morbidity, ESWL, by whatever technique (Push back or in situ) should be the primary approach for stones of less than $1 \mathrm{~cm}$ in the proximal ureter ${ }^{7}$. The non invasive nature of extra corporeal shock wave lithotripsy has a strong appeal to patients and physicians, and it has become a first line of treatment option for proximal ureteral stones ${ }^{8}$. More recently higher success rates $(81.9 \%)$ have been reported for in situ treatment of ureteral calculi using second generation lithotriptors which appears to be an attractive proposition whereas push back or ureterorenoscopy may not always success with their potential complications ${ }^{9}$. Recent data showed no improvement in fragmentation after stenting and therefore routine stent placement before ESWL was discouraged ${ }^{10}$. Shock waves consist of a single positive pressure front of multiple frequencies with a steep onset and gradual decline. Shock waves can be transmitted through water and into the body with little loss of energy or damage to the tissue. The use of shock wave in the medical field for the destruction of urinary stones is based on the some properties, which were evaluated at 6 year investigative phase ${ }^{11}$. Shock waves energy can be precisely focused by integrating the energy source into a suitable reflecting system ${ }^{12}$. So, considering all the facts it is the purpose of the study to compare the shock wave parameters (Shock wave session, number and energy) during ESWL for upper ureteric stones in in situ and push back group.

\section{MATERIALS AND METHODS}

This hospital based prospective study was carried out in the Department of Urology, Bangabandhu Sheikh Mujib Medical University (BSMMU) Dhaka from January to December, 2006. For this study, 90 patients were selected according to the selection criteria. Inclusion criteria were: Solitary stone in upper ureter, size of stone $\leq 1 \mathrm{~cm}$, no distal obstruction, and well excreting kidney in IVU. Size of stone $>1 \mathrm{~cm}$, located less than $2 \mathrm{~cm}$ lateral to the spine, urinary tract infection, pregnant women, and bleeding disorder were excluded from the study.

For this study, 50 patients were treated by in situ ESWL (Group 1) and 40 patients treated by push back and ESWL (Group 2). Detailed history was taken and clinical examination of each patient was done. All information was recorded in a predesigned data entry form. All preoperative routine investigations were done. Ultrasonogram of kidney, ureter and bladder region with post void residue, plain X-Ray KUB region (Antero-posterior and lateral view) and Intravenous
Urography (IVU) were done in all patients to see the condition of kidneys, location of stone and grade of hydronephrosis and to measure the size of stone. After taking informed written consent, under general anaesthesia, the patient was placed in modified lithotomy position with the leg opposite the involved ureter adducted while the ipsilateral leg abducted. Initial urethrocystoscopy was a routine procedure for every patient to locate the ureteric orifices and to negotiate a 0.035 guide wire. A 6-FR catheter was inserted over the guide wire. Under fluoroscopic guidance $\mathrm{C}$ - arm unit catheter was brought into the position just below the stone. The stone then was dislodged back up into the kidney with a flushing technique. Then D-J stent was placed after removing the ureteric catheter and finally position of it checked by C- arm. All the patients were catheterized with a biluminal 14-16 FR Foley's catheter for minimum of 24 hours or more when deemed necessary and advised to attend ESWL unit according to the next available waiting list. After the procedure they were discharged from lithotripsy unit on the same day if no post procedural complications like haematuria, pain and fever had occurred. Prophylactic antibiotics were given to all patients. Patients were advised to come after 7 days with a plain X-ray of KUB region. If necessary a second and a third session of ESWL were given at one week interval. If stone fails to clear even after third session of ESWL, the patients were then observed up to 90 days to see total stone clearance. Follow up cases were seen in urology outpatient department. Refractory cases were referred for other modalities of treatment. In the follow up study, history, clinical examination were done and data on post ESWL morbidity, stone passage, shock wave session, energy and stone clearance were recorded in data sheet. After collection of data and meticulous checking, statistical analysis was done using computer SPSS 12.0 version and manual technology. Test of significance were done by using students (t) test and chi square $\left(\chi^{2}\right)$ test. A probability ( $p$ value) value of $<0.05$ was considered significant.

\section{RESULTS}

Mean age of group 1 was $34.86 \pm 11.74$ years and group 2 was $35.12 \pm 12.48$ (Table 1). In group I: Overall clearance of calculi was $92.86 \%$ in stone size of $<1 \mathrm{~cm}$ and $86.36 \%$ in stone size of $1 \mathrm{~cm}$. Comparison of clearance rate among the 2 size group was not statistically significant $(\mathrm{p}>0.05)$. (Table 2$)$. In group 2: Complete clearance of stone occurred $100 \%$ in $<1 \mathrm{~cm}$ size and $88 \%$ in $1 \mathrm{~cm}$ size. Although clearance rate was higher in smaller size stone, it was not statistically significant $(\mathrm{p}>0.05)$. (Table 3). Total clearance was $90 \%$ in group 1 and $92.5 \%$ in group 2. The difference was insignificant $(\mathrm{p}>0.05)$ (Table 4). Average number of ESWL session in case of $<1 \mathrm{~cm}$ size stone were 1.54 in group 1 and 1.46 in group 2 . In case of $1 \mathrm{~cm}$ size stone, ESWL session were 1.77 in group 1, 1.48 in group 2, $(p>0.05)$ (Table 5). Considering the requirement of shock wave , less shock wave were required in group 2 (1757.50 \pm 255.09$)$ than group $1(1994 \pm 449.22)$, $(\mathrm{p}<0.01)$ (Table 6). More shock wave energy were required in group I $(5.07 \pm 0.81)$ than in group $2(4 / 63 \pm 0.48)(p<0.01)$. (Table 7$)$. Both the differences were statistically significant. 
Table 1 : Age (In years) distribution of the study population.

\begin{tabular}{lccccc} 
Groups & $\begin{array}{c}\text { No. of } \\
\text { patient }\end{array}$ & $\begin{array}{c}\text { Minimum } \\
\text { age(yrs) }\end{array}$ & $\begin{array}{c}\text { Maximum } \\
\text { age(yrs) }\end{array}$ & Mean age & SD \\
$\begin{array}{l}\text { Group-1 (In situ } \\
\text { group) }\end{array}$ & 50 & 17 & 72 & 34.86 & 11.74 \\
$\begin{array}{l}\text { Group-2 (Push } \\
\text { back and }\end{array}$ & & & & & \\
ESWL group) & 40 & 16 & 62 & 35.12 & 14.48 \\
\hline
\end{tabular}

Table 2 : Over all calculi clearance after 90 days in Group-1 (In situ ESWL).

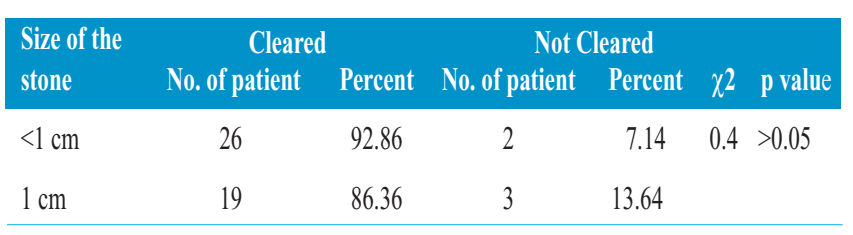

Table 3 : over all stone clearance after 90 days in Group -2 (Push back \& ESWL)

\begin{tabular}{lcccccc}
$\begin{array}{l}\text { Size of the } \\
\text { stone }\end{array}$ & \multicolumn{2}{c}{ Cleared } & \multicolumn{3}{c}{ Not Cleared } & \\
& No. of patient & Percent & No. of patient & Percent & $\chi 2$ & p value \\
$<1 \mathrm{~cm}$ & 15 & 100 & 0 & 0 & $1.94>0.05$ \\
$1 \mathrm{~cm}$ & 22 & 88 & 3 & 12 & & \\
\hline
\end{tabular}

Table 4 : Comparison of stone clearance among groups (Group -1 in situ ESWL Vs Group 2 -push back \& ESWL).

\begin{tabular}{|c|c|c|c|c|c|c|}
\hline Size of the & Clea & & Not Cl & ared & & \\
\hline stone & №. of patient & Percent & No. of patient & Percent & $x^{2}$ & $\mathrm{p}$ value \\
\hline $\begin{array}{l}\text { Group } 1 \\
\text { (In situ group) }\end{array}$ & 45 & 90 & 5 & 10 & 0.17 & $>0.05$ \\
\hline $\begin{array}{l}\text { Group } 2 \\
\text { (Push back and } \\
\text { ESWL group) }\end{array}$ & 37 & 92.5 & 3 & 7.5 & & \\
\hline
\end{tabular}

Table 5: Comparison of ESWL sessions according to stone size in the 2-groups

\begin{tabular}{lcccc} 
Groups & $\begin{array}{c}\text { Average session } \\
\text { in }<1 \text { cm size }\end{array}$ & $\begin{array}{c}\text { Average session in } \\
1 \mathrm{~cm} \text { size }\end{array}$ & $\chi^{2}$ & $\mathrm{p}$ value \\
$\begin{array}{l}\text { Group 1 } \\
\text { (In situ group) }\end{array}$ & 1.54 & 1.77 & 0.006 & $>0.05$ \\
$\begin{array}{l}\text { Group 2 } \\
\text { (Push back and }\end{array}$ & & & & \\
ESWL group) & 1.46 & 1.48 & \\
\hline
\end{tabular}

Table 6 : Comparison of shock waves needed.

\begin{tabular}{lccccccc} 
Groups & $\begin{array}{c}\text { No. of } \\
\text { patient }\end{array}$ & Minimum & Maximum & Mean & SD & t & p value \\
$\begin{array}{l}\text { Group 1 } \\
\text { (In situ }\end{array}$ & & & & & & & \\
group) & 50 & 1500 & 5000 & 1994 & 449.22 & 2.97 & $<0.01$ \\
$\begin{array}{l}\text { Group 2 } \\
\text { (Push back }\end{array}$ & & & & & & & \\
$\begin{array}{l}\text { and ESWL } \\
\text { group) }\end{array}$ & 40 & 1000 & 2000 & 1757.50 & 255.09 & & \\
\hline
\end{tabular}

Table 7 : Comparison of energy needed.

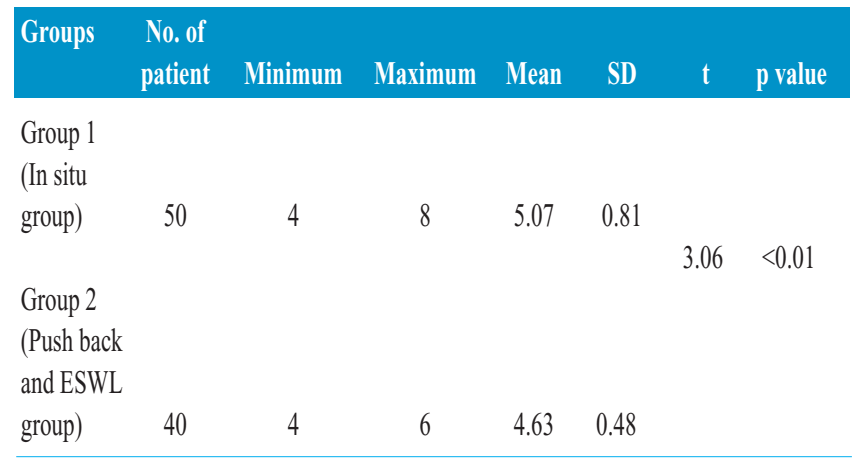

\section{DISCUSSION}

Now a day, majority of stones in the urinary tract in both adult and children can be treated by ESWL. High patient compliance and safety have made ESWL, the primary modality of treatment of stone disease Push back technique requires anesthesia and it may not always be successful with its associated risks. Not only this, it increases hospital stay and cost. Out patient and anaesthesia free treatment is attractive to most patients but they desire that the treatment to be of excellent efficacy and free of complications. In this study, the age distribution of the patients was 16 to 72 years. In group1(In situ ESWL), the age range was 17 to 72 years with a mean age $34.86 \pm 11.74$ years. In group-2 (Push back \& ESWL), the age range was 16 to 62 years with a mean age $35.13 \pm 12.48$ years. In a study, it was revealed that mean age \pm SD was $48 \pm 16$ years in ESWL in situ group and $46 \pm 16$ years in push back \& ESWL group ${ }^{6}$. In another study showed mean age of the patients in group-1 (In situ ESWL) was 35.7 years and that in group -2 (Push back \& ESWL) was 38.4 years $^{13}$. These observations are similar to the present study probably due to patients of common south Asian inhabitant.

Higher clearance rate was observed in smaller size stone than larger stones. in group 1.But the difference was not statistically significant. $(\mathrm{p}>0.05)$ Over all total clearance achieved in 45 cases $(90 \%)$ after 90 days in group -1(In situ ESWL). Higher clearance rate in larger size stone was not statistically significant $(\mathrm{p}>0.05)$. Over all total clearance achieved in 37 cases $(92.5 \%)$ after 90 days in group-2 (Push back \& ESWL).In this study, number of average ESWL sessions was 1.54 for 
$<1 \mathrm{~cm}$ stone and 1.77 for $1 \mathrm{~cm}$ stone in group -1(In situ ESWL) where as it was 1.46 for $<1 \mathrm{~cm}$ stone and 1.48 for $1 \mathrm{~cm}$ stone in group-2 (Push back \& ESWL). Although less number of ESWL sessions required in manipulation group it was statistically not significant ( $\mathrm{p}>0.05$ ).

A separate study showed that $1.86 \pm 1.2$ sessions required in group- 1 and $2.03 \pm 1.2$ sessions required in group $-2(p=0.28)^{13}$. The variation of needed ESWL sessions can be due to variation in stone size and type of lithotriptors used by individual reseach person.

In this study, more shock wave and energy needed in group1(In situ ESWL) than in group-2 (Push back \& ESWL). Mean shock wave was1994 \pm 449 in group- 1 and $1757.5 \pm 255$ in group-2.The difference between the two is very significant $(\mathrm{p}<0.01)$. Mean shock wave was $5.07 \pm 0.81 \mathrm{KV}$ in group-1 and $4.6 \pm 0.48 \mathrm{KV}$ in group-2 . The difference between the two was also statistically very significant $(p<0.01)$. Another study mentioned more shock wave and energy in group-1 than in group-2. Mean No. of shock wave s \pm SD $1844 \pm 639$ in group1 and $1297 \pm 437$ in group- 2 and mean KV on electrodes \pm SD $19.5 \pm 1.4$ in group- $1 \& 18.7 \pm 0.9$ in group $-2(p<0.001)^{6}$. This result was compatible with the present study.

\section{CONCLUSION}

Although more ESWL sessions were required in group 1 (In situ ESWL) than group 2 (Push back and ESWL), it was not statistically significant $(p>0.01)$. But mean shock wave number and energy were higher in group 1 than group 2 which was statistically significant $(\mathrm{p}<0.01)$ for upper ureteric calculi.

\section{DISCLOSURE}

All the authors declared no competing interest.

\section{REFERENCES}

1. Stoller ML, Bolton DM. Urinary Stone Disease. In Tangaho EA, Mcaninch JW (eds), Smith's General Urology. $15^{\text {th }}$. ed. Lange medical books /McGraw-Hill, Sanfrancisco. 200;291-320.

2. Salam MA. Urinary stone disease. Principles and Practice of Urology. MAS Publications, Dhanmondi Residential Area, Dhaka. 2002;721-740

3. Martin X, Tolley D, Galluci M, Alken P. The difficult stone case: Definition and management. European Urology. 2001;40:1-9.

4. Marshall L. Stoller MD. Extracorporeal Shockwave lithotripsy. In : Smith's General Urology . $15^{\text {th }}$ ed. Lange medical books/ McGraw Hill, Sanfrancisco. 2000;321-329.

5. Shameem I. A, Islam K, Islam AKMA, Salam M A, Wahab M.A. Management of ureteral stones by in situ ESWL. Bangladesh Journal of Urology. 2001; $4: 14-15$.

6. Danuser H, Ackerman D K, Marth D C, Studer U E and Zingg E J. Extra corporeal shock wave lithotripsy in situ or after push- up for upper ureteric calculi . The Journal of Urology. 1993; $150:$ 824-826.

7. Menon M, REsnick MI. Urinary lithiasis : Etiology, Diagnosis and Medical management in Walsh PC, Retik AB, Vaugan ED Jr. and Wein AJ et al. (eds) Campbell's Urology, $8^{\text {th }}$ ed. Philadelphia, WB Saunders. 2002;3229-3305.

8. Liong M L, Clayman R.V, Gittes R F, Lingeman J E, Huffman J L and Lyon E S. Treatment options for proximal ureteral urolithiasis : review and recommendations. The Journal of Urology. 1988; $140: 504-507$.

9. Holden D, Rao P N . Ureteral stones : The results of primary in situ extra corporeal shock wave lithotripsy . The Journal of Urology. 1989; 142: 37-39.

10. Mobley TB, Myers DA ,Jenkins JM, et al : Treatment results with 18,825 calculi using Lithistar lithotripter. The Journal of Urology. 1994; $152: 53-56$.

11. McCullough DL.Extracorporeal shock wave lithotripsy. In: Walsh PC, Retik AB, Stamey TA and Vaughan ED .Jr.(eds). Campbell's Urology, $8^{\text {th }}$ ed. Philadelphia : WB Saunders company. $1996 ; 2151-2182$.

12. Chaussy C, Brandel W, and Schmidt E . Extra corporeally induced destruction of kidney stones by shock wave. Lancet. 1980; 2: 1265-1269.

13. Kumar A, Kumar V R, Mishra V K, Ahlawat R, Kapoor R, and Bhandari M. : Should upper ureteric calculi be manipulated before extra corporeal shock wave lithotripsy? A prospective controlled trial . The Journal of Urology. 1994; 152: 320-323. 